JSI 7 (3) (2018)
Jurnal Sastra Indonesia

\title{
EMOSI TOKOH-TOKOH SENTRAL DALAM NOVEL SUNSET BERSAMA ROSIE KARYA TERE LIYE
}

\section{Rahmawati, Sumartini, Maharani Intan Andalas IRP}

Jurusan Bahasa dan Sastra Indonesia, Fakultas Bahasa dan Seni, Universitas Negeri Semarang, Indonesia

\section{Info Artikel}

Sejarah Artikel:

Diterima Agustus 2018

Disetujui Oktober 2018

Dipublikasikan November 2018

Keywords:

Emotion, psychological conflict, novel Sunset with Rosie.

\begin{abstract}
Abstrak
Penelitian ini bertujuan untuk mendeskripsikan klasifikasi emosi, konflik psikologis, dan sikap dalam menghadapi konflik psikologis dalam novel Sunset Bersama Rosie karya Tere Liye. Pendekatan yang dilakukan dalam penelitian ini adalah pendekatan psikologi sastra yaitu telaah karya sastra yang mencerminkan proses dan aktivitas kejiwaan. Penelitian ini menggunakan metode penelitian deskriptif kualitatif. Sasaran penelitian ini adalah klasifikasi emosi tokoh tokoh sentral dalam novel Sunset Bersama Rosie karya Tere Liye. Data penelitian ini adalah penggalan teks yang menunjukkan emosi tokoh-tokoh sentral dan sumber data penelitian ini adalah novel Sunset Bersama Rosie karya Tere Liye. Teknik pengumpulan data menggunakan teknik baca dan catat. Berdasarkan hasil penelitian, ditunjukkan bahwa klasifikasi emosi yang dialami tokoh-tokoh sentral terdiri atas rasa bersalah, menghukum diri sendiri, rasa malu, kesedihan, kebencian, dan cinta. Konflik psikologis yang dialami tokoh-tokoh sentral terdiri atas approach-approach conflict, approach-avoidance conflict, dan avoidance-avoidance conflict. Sikap yang ditunjukkan tokoh-tokoh sentral dalam novel Sunset Bersama Rosie karya Tere Liye dipengaruhi konflik yang dialami. Namun, tidak semua tokoh-tokoh sentral bersikap sama terhadap konflik psikologis yang dialami. Beberapa tokoh-tokoh sentral yang dapat bersikap berkebalikan dari emosi mereka.
\end{abstract}

\section{Abstract}

This study aims to describe the classification of emotions, psychological conflict, and attitude in the face of psychological conflict in the novel Sunset alongside Rosie work of Tere Liye. The approach was conducted in this research is the psychology literature approach i.e. review literary works that reflect the procesess and activity of psychological abuse. This research uses descriptive qualitative research methods. The target of this research is the classification of the emotions of the character the central character in the novel Sunset alongside Rosie work of Tere Liye. This research data is extract text that shows the emotions the central figures and data source this study is novel Sunset alongside Rosie work off Tere Liye. Data collection techniques using readand write down. Based on the result of the study, pointed out that the classification of emotions experienced by central figures composed of guilt, punish yourself, shame, sorrow, hatred, and love. Psycholigical conficts that plagued central figures composed of approach-approach conflict, approachavoidance conflict, and avoidance-avoidance conflict. The attitude shown the central figures in the novel Sunset ALONGSIDE Rosie work of Tere Liye influenced confict is experienced. Howefer, not all central figures in the same attitude toward psychological conflict. Some of the central figures who can be the opposite of their emotions.

(C) 2018 Universitas Negeri Semarang

Gedung B1 Lantai 1 FBS Unnes

Kampus Sekaran, Gunungpati, Semarang, 50229

E-mail : rahmawati@gmail.com 


\section{PENDAHULUAN}

Sastra adalah suatu kegiatan kreatif sebuah karya seni. Namun istilah "sastra" dapat diterapkan pada seni sastra yaitu sastra sebagai karya imajinatif. Keistimewaan sastra yaitu penggunaan bahasanya yang indah. Untuk mengerti makna di balik karya sastra, dibutuhkan pengalaman, pemahaman yang mendalam terhadap karya sastra, dan cara membedakan bahasa khas sastra yaitu dengan membedakan bahasa sehari-hari dan bahasa ilmiah. Bahasa sastra penuh ambiguitas dan homonim serta memiliki kategori-kategori yang tidak beraturan dan tidak rasional. Bahasa sastra juga penuh dengan asosiasi dan simbolisme yang mengacu pada ungkapan atau karya yang diciptakan sebelumnya. Dengan kata lain, bahasa sastra sangat "konotatif" sifatnya (Rene Wellek \& Warren, 1995: 15).

Sebenarnya sastra dan psikologis dapat bersimbiosis dalam peranannya terhadap kehidupan karena keduanya memiliki fungsi dalam hidup ini. Keduanya sama-sama berurusan dengan persoalan manusia sebagai makhluk individu dan makhluk sosial. Keduanya memanfaatkan landasan yang sama yaitu menjadikan pengalaman manusia sebagai bahan telaah. Oleh karena itu, pendekatan psikologis dianggap penting penggunaannya dalam penelitian sastra (Endraswara, 2008:15). Gejala-gejala psikologis tersebut tidak secara langsung diceritakan oleh pengarang, tetapi diceritakan melalui perwatakan tokohnya.

Salah satu novel yang memuat permasalahan berupa emosi, konflik, dan sikap tokoh ialah Sunset Bersama Rosie karya Tere Liye. Novel Sunset Bersama Rosie merupakan novel yang sarat dengan psikologi kepribadian tokoh-tokoh sentralnya. Sunset berasal dari kata bahasa Inggris yang berarti matahari tenggelam. Secara harfiah, sunset bersama Rosie memiliki arti menghabiskan waktu bersama Rosie melihat matahari tenggelam.

Gambaran perasaan emosi tokoh yang dilukiskan pengarang seolah-olah nyata atau realistis. Pengarang memasukkan perasaan yang kuat dalam diri masing-masing tokohtokoh sentral sehingga sering terjadi konflik psikologis yang membuat tokoh-tokoh sentral dalam novel ini harus mengambil sikap yang bertentangan dengan emosinya. Oleh karena itu, tokoh-tokoh ini berada dalam tekanan konflik psikologis, yaitu suatu pertentangan batin, suatu kebimbangan, suatu keraguraguan, motif mana yang akan diambil, dan di situlah sikap tokoh sangat diperlukan dalam menyikapi konflik psikologis yang dialaminya. Seperti ketika Nathan meninggal akibat bom Bali, Rosie dan anak-anaknya berkabung. Rosie yang tidak bisa menerima kematian Nathan yang tiba-tiba itu mengalami depresi hebat. Ia mulai melakukan tindakan bodoh seperti bunuh diri, tetapi tindakan itu bisa dicegah karena Tegar segera memanggil dokter. Karena, upaya bunuh diri tersebut gagal Rosie mengurung diri di kamar dan mulai berteriak-teriak seperti orang gila, ia pun mulai menyakiti putri-putrinya yang mendekatinya. Tegar yang saat itu mau tidak mau harus mengambil keputusan berat untuk mengirim Rosie ke Shelter yang berada di Bali.

Tekanan psikologis yang dialami Rosie pun berimbas pada keempat putrinya. Sakura yang biasanya ceria kini menjadi anak yang pendiam. Anggrek yang umurnya dua belas tahun dituntut untuk menjadi contoh yang baik untuk adik-adiknya, dan Jasmine berusaha menjadi ibu untuk adiknya lili yang baru berumur dua tahun. Mereka harus menerima cemooh teman-teman sekolahnya yang terus menjelek-jelekkan kedua orang tuanya. Tekanan psikologis tokoh-tokoh setral novel Sunset Bersama Rosie Karya Tere Liye tidak hanya sampai di situ.

Tere Liye adalah salah satu pengarang Indonesia yang banyak mengeluarkan karyakarya best seller. Tere Liye dikenal melalui karya-karyanya yang sarat dengan kritik sosial dan psikologis. Novel Sunset Bersama Rosie merupakan novel kedua belas Tere Liye yang diterbitkan tahun 2011 setelah novel Ayahku (Bukan) Pembohong (2011). Novel Sunset Bersama Rosie ini merupakan salah satu novel yang sarat dengan emosi karakter tokoh. Novel ini mengangkat kisah tentang sesosok pria yang memiliki masa lalu kelam tentang perasaan cinta yang tidak pernah tersampaikan kepada teman masa kecilnya. Pria itu bernama Tegar Karang.

Beberapa alasan yang menyebabkan novel ini penting untuk dikaji yaitu yang pertama, emosi tokoh-tokoh sentral atau tokoh utama (Tegar, Rosie, Anggrek, Sakura, 
Yasmin, dan Lili) yang menghadapi banyak konflik, ada tiga macam konflik yang dialami tokoh-tokoh sentral menurut Kurt Lewin (dalam Bimo Walgito) yaitu approach-approach conflict, approach-avoidance conflict, avoidanceavoidance conflict. Kedua, novel ini menceritakan kehidupan anak-anak yang kehilangan kedua orang tuanya akibat bencana bom Bali sehingga memiliki relevansi dengan dampak masa sekarang. Ketiga sikap tokoh-tokoh sentral yang ditunjukkan bertolak belakang dengan emosi yang sedang dialami. Hal inilah yang membuat tokoh-tokoh sentral penting untuk diteliti.

\section{METODE PENELITIAN}

Penelitian ini menggunakan pendekataan psikologi sastra. Pendekatan psikologi sastra adalah pendekatan yang mempelajari kejiwaan manusia yang tercermin dalam perilaku yang nyata. Penelitian ini difokuskan pada jenis-jenis emosi yang dialami tokoh-tokoh sentral secara psikologis.

Secara khusus, penelitian ini menggunakan teori Krech tentang klasifikasi emosi. Emosi merupakan merujuk pada suatu perasaan dan pikiran yang khas, suatu keadaan biologis dan psikologis dan serangkaian kecenderungan untuk bertindak. Jenis-jenis emosi ada tujuh yaitu rasa bersalah, rasa bersalah yang dipendam, menghukum diri sendiri, rasa malu, kesedihan, kebencian, dan cinta.

Data yang dijadikan objek dalam penelitian ini adalah penggalan teks yang menunjukkan emosi tokoh-tokoh sentral dalam novel Sunset Bersama Rosie karya Tere Liye. Sumber data dalam penelitian ini adalah novel ini Sunset Bersama Rosie karya Tere Liye. Novel ini diterbitkan oleh Mahaka Publishing; Jakarta pada tahun 2011 cetakan pertama dengan tebal 20,5 cm dan 426 halaman. Data lain yang dapat mendukung adalah buku teori dan buku acuan lain yang digunakan peneliti untuk mendukung jalannya penelitian, yaitu buku tentang teori psikologi sastra, psikologi kepribadian, dan buku-buku lain yang mendukung penelitian ini.

Teknik pengumpulan data yang digunakan adalah teknik baca catat yaitu membaca dan memahami seluruh jalan cerita novel Sunset Bersama Rosie karya Tere Liye, kemudian mencatat hal-hal yang berkaitan dengan masalah yang akan diteliti.
Pengumpulan data dalam penelitian ini yaitu dengan mencari jenis-jenis emosi tokoh-tokoh sentral, konflik psikologis, sikap tokoh-tokoh sentral dalam menghadapi emosi tersebut.

$$
\text { Hasil analisis dideskripsikan }
$$

berdasarkan data-data yang terkumpul, baik berupa kalimat, paragraf yang terdapat dalam sumber data, yakni pada novel Sunset Bersama Rosie karya Tere Liye. Untuk membantu memahami dan menentukan sifat keadaan dan suatu kasus tertentu dalam karya sastra yang diteliti, diperlukan kegiatan interpertasi, misalnya untuk memahami dan menentukan mana yang merupakan kasifikasi emosi dan yang mana yang bukan klasifikasi emosi.

Teknik deskriptif kualitatif digunakan karena memang data-data dalam penelitian ini berupa kata, kalimat, atau paragraf yang berada di dalam cerita, sehingga bentuknya data kualitatif. Penjelasan dalam paragraf ini dilakukan secara deskriptif, dalam hal ini peneliti menampilkan penjelasan mengenai segala sesuatu yang menunjukkan adanya klasifikasi emosi tokoh-tokoh sentral dalam cerita novel.

\section{HASIL PENELITIAN DAN PEMBAHASAN}

Hasil penelitian tentang emosi tokohtokoh sentral dalam novel Sunset Bersama Rosie karya Tere Liye disajikan dalam tiga bagian masalah, meliputi: (1) jenis-jenis emosi yang dialami tokoh-tokoh sentral dalam novel Sunset Bersama Rosie karya Tere Liye, (2) konflik psikologis yang dialami tokoh-tokoh sentral dalam novel Sunset Bersama Rosie karya Tere Liye, (3) sikap yang ditunjukkan tokohtokoh sentral dalam novel Sunset Bersama Rosie karya Tere Liye. Hasil penelitian berupa data deskriptif yaitu kutipan pada novel beserta penjelasannya.

\section{Klasifikasi Emosi Tokoh-Tokoh Sentral Novel Sunset Bersama Rosie}

klasifikasi emosi dibagi menjadi tujuh jenis. Namun, dalam Sunset Bersama Rosie karya Tere Liye ditemukan lima jenis emosi yaitu rasa bersalah, menghukum diri sendiri, kebencian, kesedihan, dan cinta.

(1) Rasa Bersalah,

Rasa bersalah bisa disebabkan oleh adanya konflik antara ekspresi impuls dan standar moral. ekpresi impuls artinya ekspresi perasaan sedangkan standar moral yaitu 
perbuatan atau tingkah laku atau ucapan seseorang dalam berinteraksi dengan manusia sesuai dengan nilai rasa yang berlaku di masyarakat seperti yang dialami Tegar.

"Aku, aku ada di Bali."

Tercekat. Semua ini benarbenar membuat lupa. Kepanikan semalam membuatku lupa kalau hari ini hari penting bagiku. Pertunangan kami.

Suara riang Sekar mendadak menghilang. Lengang.

"Maafkan aku, membuat kacau-balau rencana besar kita. Maafkan aku lupa melepon kau segera, Sekar." Aku mendesis lemah setelah hening sesaat.

"Tidak apa-apa. Aku akan bilang Papa dan Mama, acaranya dibatalkan." Sekar berkata amat lirih

Aku mendadak merasa

bersalah. (Sunset Bersama

Rosie Hlm. 49-51)

Tegar benar-benar lupa tentang hari penting mereka. Namun, Tegar berusaha menjelaskan keadaan mengapa dia langsung bergegas ke Bali tanpa pikir panjang lagi. Tegar juga menunjukkan rasa bersalah pada Sekar dan keluarga, dan ia juga berniat meminta maaf pada Sekar dan keluarganya dalam waktu satu minggu ke depan.

(2) Menghukum diri sendiri

Menghukum diri sendiri, perasaan bersalah yang paling mengganggu yakni sebagaimana terdapat dalam sikap menghukum diri sendiri, ketika si individu merasa sebagai sumber dari sikap bersalah.

"Perusahaan sekuritas ternama itu cocok dengan yang kubutuhkan. Mereka menuntutku bekerja sepuluh jam sehari. Berangkat pagi pulang larut malam. Yes, aku membutuhkan semua itu, maka bagai mesin aku membenamkan diri dengan segala rutinitas dan pekerjaan menyebalkan. Menggunakan seluruh energiku untuk bekerja. Dengan lelah bekerja itu berarti janji tidur yang

nyenyak malam ini.

Membuat seluruh otakku

melupakan Rosie." (Sunset

Bersama Rosie, hlm. 69).

Tegar tidak hanya menghukum dirinya sendiri dengan mengurung diri di kamar, tetapi dia juga menyibukkan dirinya dengan cara bekerja selama sepuluh jam sehari tanpa mengistirahatkan tubuhnya agar pikirannya tidak mengingat Rosie, untuk membunuh rasa rindunya setiap kali perasaan itu datang.

(3) Kesedihan

Kesedihan berhubungan dengan kehilangan sesuatu yang penting atau bernilai.

Setengah jam berlalu.

Pemakaman hanya

meninggalkan kami. Angin

pagi membelai anak rambut.

Menelisik belakang daun

telinga. Rosie masih tetap diam

membeku. Tidak bergerak satu

mili pun. Wajahnya sempurna

kosong tanpa kedutan. Tanpa

lipatan. (Sunset Bersama Rosie,

hlm. 78)

Emosi kesedihan membuat tokoh Rosie lupa akan waktu. Emosi kesedihan tersebut membuat Rosie tidak bisa menerima kenyataan. Rosie diam membeku tanpa menghiraukan orang-orang sekelilingnya yang menunggu untuk kembali ke resor.

(4) Kebencian

Kebencian atau perasaan benci (hate) berhubungan erat dengan perasaan marah, cemburu dan iri hati.

Di tahun keenam, kejutan besar, Rosie dan Nathan tibatiba mengunjungiku di Jakarta. Entah bagaimana mereka tahu alamatku. Padahal sejak kepergian itu, aku memutuskan merahasiakan banyak hal. Aku, Nathan, dan Rosie sama-sama anak tunggal, dengan sanak kerabat terbatas. Tidak banyak yang tahu aku tinggal di Jakarta. Jadi menatap wajah Rosie yang datang membawa Anggrek dan Sakura mendadak membuatku membeku. Kesedihan itu. Kebencian itu. $\mathrm{Aku}$ kebas menahan marah, 
menerima kehadiran mereka di depan pintu apartemen. Tetapi ya Tuhan, keajaiban itu terjadi.

(Sunset Bersama Rosie, hlm.

10)

Tegar merasakan emosi kebencian ketika melihat Rosie dan Nathan datang ke apartemennya dengan membawa serta kedua anak mereka. Enam tahun Tegar harus menanggung semua kebencian itu sendiri dan setiap kali bayangan di atas gunung Rinjani itu terulang, ia harus menahan semua rasa cintanya pada Rosie.

(5) Cinta

Cinta adalah perasaan yang kuat akan ketertarikan kepada pihak lain dengan harapan bahwa dia juga memiliki perasaan yang sama.

"Rosie, aku mencintaimu. Aku tidak pernah mengerti perasan itu, tetapi aku mencintaimu sejak kau masih berkepang dua. Sejak kita masih cemong air sawah. Mengejar capung. Menangkap kodok hijau meski kau jijik sekali." (Sunset Bersama Rosie, hlm. 31)

Tegar mengalami emosi cinta meskipun ia sendiri tidak begitu paham apa arti cinta tetapi Tegar mengakui bahwa ia mencintai Rosie ketika Rosie masih berkepang dua, bajunya kotor karena main ke sawah, bahkan ketika mereka berlari mengejar capung serta menangkap kodok hijau yang sangat dibenci Rosie. Tegar sudah mencintai Rosie.

2. Konflik Psikologis yang Dialami Tokoh-Tokoh Sentral dalam Novel Sunset Bersama Rosie Karya Tere Liye

Dalam novel ini, ditemukan ada tiga macam konflik motif menurut Kurt Lewin (dalam Bimo Walgito) yaitu approach-approach conflict (konflik angguk-angguk), approachavoidance conflict (konflik geleng-angguk), dan avoidance-avoidance conflict (konflik gelenggeleng).

(1) Approach-Approach Conflict (Konflik Angguk-angguk).

konflik yang timbul apabila individu menghadapi dua motif atau lebih yang kesemuanya mempunyai nilai positif bagi individu yang bersangkutan, dan individu tersebut harus mengadakan pemilihan di antara motif-motif yang ada.
Hari ini aku menghadiri peletakan batu pertama enam belas unit bungalow di dekat cadas dreamland. Cabang baru resor Gili Trawangan. Made membantu mengurusnya. Enam belas bungalow, tidak mewah, tapi pasti amat klasik. Seperti rumah-rumah yang ditempelkan di cadas pantai. $\mathrm{Aku}$ menghabiskan seluruh tabungan, dan meminjam dua pertiga kekurangannya dari bank semoga investasi itu tidak sia-sia. Sudah saatnya resor sederhana warisan keluarga Rosie bergerak maju. (Sunset Bersama Rosie, hlm. 200).

Jadi sekalian dari lokasi pembangunan bungalow, aku menuju shelter Rosie. Lazimnya kalau aku yang sendirian berkunjung, maka Anggrek bersiap dengan layar televisi. (Sunset Bersama Rosie, hlm. 200).

Tegar memilih menghadiri peletakan batu pertama enam belas unit bungalow yang ada di Bali. Meskipun Tegar mendatangi shelter tempat Rosie Tegar memutuskan untuk tidak menemui Rosie karena dia tidak ingin mengganggu waktu istirahat Rosie.

(2) Approach avoidance conflict.

Konflik yang timbul apabila individu menghadapi motif yang mengandung nilai positif, tetapi juga menghadapi nilai negatif, hal ini dapat menimbulkan konflik pada individu yang bersangkutan.

"KAU GILA, TEGAR! Tiga

belas tahun kau bekerja

untukku, tiba siposisimu sekarang dengan cepat. Seluruh reputasimu! Dan kau meneleponku, dengan menyela acara bermain golf-ku hanya untuk bilang kau ingin berhenti bekerja! Berhenti begitu saja! OMONG KOSONG!" (Sunset

Bersama Rosie, hlm. 163).

Tegar mengalami dilema karena bosnya mengatakan bahwa Tegar akan naik jabatan sedangkan pada saat itu Tegar bermaksud mengundurkan diri dari perusahaan tersebut. 
Bosnya memberi waktu dua minggu untuk memikirkan ulang keputusan tersebut. Tetapi Tegar ingin fokus mengurus anak-anak selama Rosie menyembuhkan diri di shelter. jadi, ia memutuskan keluar dari perusahaan tersebut.

(3) Avoidance-avoidance conflict.

Konflik yang timbul apabila individ menghadapi dua atau lebih motif yang kesemuanya mempunyai nilai negatif bagi individu yang bersangkutan. Individu tidak boleh menolak semuanya, tetapi harus memilih salah satu dari motif-motif yang ada.

"PERGI KAU!"

"ROS! ITU LILI. AKU
MOHON SADARLAH"
Rosie terus menyeret Lili
mendekati tiang pembatas
pondok.
Aku melangkah gemetar. Ya
Tuhan apa yang akan
dilakukan Rosie. (Sunset
Bersama Rosie, hlm. 204).

Rosie yang berteriak histeris menyuruh semua orang yang berada di sekelilingnya pergi menjauhinya sambil menarik anaknya Lili, membuat Tegar seketika itu dilanda kepanikan yang luar biasa. Tegar berusaha membujuk Rosie untuk melepaskan cengkeramannya di leher Lili namun sia-sia, Rosie malah semakin berteriak histeris dan menyuruh semuanya pergi.

\section{Sikap Tokoh-Tokoh Sentral dalam Menghadapi Konflik}

Sikap atau attitude merupakan sikap pandangan atau sikap perasaan, tetapi sikap tersebut disertai dengan kecenderungan untuk bertindak sesuai dengan sikap individu itu. Jadi, sikap bisa dikatakan sebagai sikap atau kesediaan beraksi terhadap suatu hal.

(1) Sikap Tokoh Sentral dalam Menghadapi Approach-Approach Conflict (Konflik Angguk-angguk)

Tegar menghadapi dua konflik positif yang mengharuskannya memilih antara kedua konflik tersebut, sehingga dia dapat mengambil sikap yang menurutnya terbaik di antara kedua konflik.

Hari ini aku menghadiri peletakan batu pertama enam belas unit bungalow di dekat cadas dreamland. Cabang baru resor Gili Trawangan. Made membantu mengurusnya. Enam belas bungalow, tidak mewah, tapi pasti amat klasik. Seperti rumah-rumah yang ditempelkan di cadas pantai. $\mathrm{Aku}$ menghabiskan seluruh tabungan, dan meminjam dua pertiga kekurangannya dari bank semoga investasi itu tidak sia-sia. Sudah saatnya resor sederhana warisan keluarga Rosie bergerak maju. (Sunset Bersama Rosie, hlm. 200).

Jadi sekalian dari lokasi pembangunan bungalow, aku menuju shelter Rosie. Lazimnya kalau aku yang sendirian berkunjung, maka Anggrek bersiap dengan layar televisi. (Sunset Bersama Rosie, hlm. 200).

Sikap atau keputusan yang Tegar ambil untuk menyelesaikan konflik tersebut adalah Tegar memutuskan menetap di Gili Trawangan dan bekerja meneruskan usaha yang dijalankan oleh keluarga Rosie namun dia juga ingin resor yang dikembangkan oleh ayah Rosie bisa terkenal, jadi, Tegar menginvestasikan seluruh tabungannya untuk membangun bungalow klasik di Bali.

(2) Sikap Tokoh Sentral dalam Menghadapi Approach-Avoidance Conflict (Konflik Geleng-angguk)

Tegar yang dilema karena harus mengambil sikap ketika dihadapi konflik positif dan konflik negatif dan harus memilih antara kedua konflik tersebut.

Terkesiap. Ya Tuhan, apa yang telah Rosie lakukan. Seperti seekor elang aku melompat ke tepi ranjang, mendekati Rosie yang terbaring dengan mulut berbusa. Oma terlihat gemetar di dekatnya, bingung hendak melakukan apa. Mataku buas menyapu seluruh tubuh Rosie. Selongsong botol obat tidur tergeletak di dekat bantal. Aku panic merengkuh tubuh itu, menyeka bibirnya. 
(Sunset Bersama Rosie, hlm.

104).

Tegar segera memanggil Mitchel untuk menolong Rosie, berkat Mitchell nyawa Rosie bisa diselamatkan. Tegar mengambil sikap untuk tidak menceritakan tentang kondisi Rosie pada anak-anak karena Tegar tidak ingin anak-anak bertambah bersedih karena mengetahui kodisi ibunya.

(3) Sikap Tokoh Sentral dalam Menghadapi Avoidance-Avoidance Conflict (Konflik Geleng-Geleng)

Tegar yaitu antara menyaksikan Rosie yang membawa Lili melompati pagar karena depresi Rosie yang tiba-tiba kambuh atau memilih mengungkapkan masa lalunya yang kelam di depan Rosie.

"PERGI KAU!"

"ROS! ITU LILI. AKU

MOHON SADARLAH"

Rosie terus menyeret Lili mendekati tiang pembatas pondok.

Aku melangkah gemetar. Ya

Tuhan apa yang akan

dilakukan Rosie. (Sunset

Bersama Rosie, hlm. 204).

Sikap atau keputusan yang Tegar ambil untuk menyelesaikan konflik tersebut adalah Tegar memutuskan untuk mengatakan masa lalunya pada Rosie dan anak-anak supaya Rosie mengurungkan diri melompati pagar pembatas pondok bersama Lili.

\section{PENUTUP}

\section{SIMPULAN}

Berdasarkan pembahasan pada bab sebelumnya, simpulan yang dapat dikemukakan adalah sebagai berikut. Emosi yang dialami tokoh-tokoh sentral dalam novel Sunset Bersama Rosie karya Tere Liye yang terdapat dalam penelitian ini ada lima emosi yang meliputi; rasa bersalah, menghukum diri sendiri, kesedihan, kebencian, dan cinta. Konflik psikologis yang dialami tokoh-tokoh sentral dalam novel Sunset Bersama Rosie karya Tere Liye yang terdapat dalam penelitian ini ada tiga yaitu approach approach conflict, approach avoidance conflict, dan avoidance avoidance conflict. Sikap yang ditunjukkan tokoh-tokoh sentral dalam novel Sunset Bersama Rosie karya Tere Liye sama dengan konflik yang dialami. Namun, tidak semua tokoh-tokoh sentral mengambil sikap sama dengan konflik psikologis, ada beberapa tokoh-tokoh sentral yang dapat bersikap berkebalikan dari emosi mereka.

\section{SARAN}

Berdasarkan simpulan yang dikemukakan, saran yang dapat diberikan adalah sebagai berikut. Hasil penelitian ini diharapkan dapat dimanfaatkan oleh pembaca tentang mengetahui emosi-emosi dasar manusia dan memahami kondisi manusia ketika menghadapi emosi tersebut. Kajian tentang Novel Sunset Bersama Rosie karya Tere Liye dengan menggunakan pendekatan psikologi sastra telah berhasil diselesaikan. Namun, masih banyak pendekatan lain yang dapat dikaji novel ini seperti sosiologi sastra, resepsi sastra, kritik sastra dan sebagainya.

\section{UCAPAN TERIMA KASIH}

Puji syukur peneliti haturkan ke hadirat Allah Swt. karena telah memberikan rahmat dan hidayah yang tiada bertepi, sehingga peneliti berhasil menyelesaikan skripsi ini. Penyelesaian skripsi ini tidak terlepas dari bantunan dan bimbingan pihak lain. Oleh karena itu, peneliti meyampaikan ucapan terima kasih kepada Sumartini,S.S.,M.A., dan Maharani Intan Andalas IRP., S.S., M.A., yang telah dengan tulus, ikhlas, dan penuh kesabaran memberikan arahan dan bimbingan kepada penulis. Tidak lupa juga peneliti mengucapkan terima kasih kepada keluarga dan teman-teman Jurusan Bahasa dan Sastra Indonesia yang telah sama-sama berjuang serta memberi semangat dan dorongan satu sama lain sehingga peneliti dapat menyelesaikan penelitian ini dengan baik.

\section{DAFTAR PUSTAKA}

Endraswara, Suwardi. 2013. Metodologi Penelitian Sastra. Yogyakarta: Center for Academic Publishing Service.

Gerungan, W.A. 2010. Psikologi Sosial. Bandung: PT Refika Aditama.

Hanurawan, Fattah. 2015. Psikologi Sosial Suatu Pengantar. Bandung: Rosada.

Liye, Tere. 2011. Sunset Bersama Rosie. Jakarta: Mahaka Publishing. 
Minderop, Albertine. 2011. Psikologi Sastra. Jakarta: Yayasan Pustaka Obor Indonesia

Walgito, Bimo. 2010. Pengantar Psikologi Umum. Yogyakarta;Penerbit Andi.

Wellek, Rene dan Austin Warren. 1995. Teori Kesusasteraan. Jakarta: PT Gramedia Pustaka Utama. 